\title{
Pengaruh Minat Usaha dan Motivasi Usaha terhadap Keberhasilan Usaha Wirausaha Muda di Kota Langsa
}

\author{
Dyah Ayu Ardiyanti \\ Fakultas Ekonomi Universitas Samudra, Langsa \\ e-mail: dyahayu.ardianti@unsam.ac.id \\ Zulkarnen Mora \\ Fakultas Ekonomi Universitas Samudra, Langsa \\ e-mail: zulkarnen.mora@unsam.ac.id
}

\begin{abstract}
This research aims to determine whether there is an influence of interest and motivation towards the success of the business of young entrepreneurs in the City of Langsa. The methodology of this research is a quantitative method with an unknown population. The sample chosen used purposive sampling technique amounted to 125 respondents. The research invention are proven by conducting multiple linear regression analysis that is $Y=\alpha+\beta_{1} X_{1}+\beta_{2} X_{2}+e$. The results of the study were obtained using SPSS version 16 and the results showed that business interest partially affected the success of the business. But partially business motivation does not affect the success of the business. Whereas business interests and business motivation simultaneous have a positive effect on business success. Coefficient of determination $\left(R^{2}\right)$ obtained is only 0.04, which means that only $4 \%$ of business success is influenced by the business interests and business motivations. While the remaining 96\%, business successfull depends on other variables outside of this research variable
\end{abstract}

Keywords: Business Interest, Business Motivation, Success of Business, Young Entrepreneurs.

\section{PENDAHULUAN}

Dewasa ini jenis usaha mikro, kecil dan menengah (UMKM) mempunyai peran penting dalam pembangunan ekonomi nasional. Selain berperan dalam pertumbuhan ekonomi serta pemerataan pendapatan, kelompok usaha itu juga sangat bermanfaat dari sisi penyerapan tenaga kerja sehingga dapat mengurangi tingkat pengangguran.

Berdasarkan data yang dikeluarkan oleh BPS Kota Langsa, diketahui jumlah penduduk kota Langsa tahun 2017 adalah sebanyak 171.574 jiwa dengan kelompok usia produktif (usia 15 - 64 tahun) berjumlah 113.252 jiwa. Pada tahun yang sama, Tingkat Partisipasi Angkatan Kerja (TPAK) Kota Langsa sebesar 70,84 persen dan Tingkat Pengangguran
Terbuka (TPT) sebesar 7,03 persen, lebih baik daripada tahun 2015 yaitu dengan TPAK sebesar 63,43 persen dan TPT sebesar 8,55 persen. Dari data juga diperoleh bahwa jumlah pengangguran di Kota Langsa banyak disumbang dari lulusan SMA umum, yaitu sebanyak 60,69 persen.

Data yang telah diuraikan tersebut menunjukkan terjadi penurunan jumlah pengangguran sebesar 1,52 persen. Kondisi ini diharapkan dapat terus mengalami peningkatan sehingga angka pengangguran dapat semakin ditekan.

Salah satu penyebab menurunnya tingkat pengangguran tersebut adalah karena meningkatnya pertumbuhan ekonomi pada kategori penyediaan akomodasi dan makan 
minum secara signifikan. Kategori ini mencatat laju pertumbuhan positif sebesar 14,63 persen pada tahun 2017. Meningkat apabila dibandingkan tahun 2016 yang tumbuh sebesar 11,12 persen.

Hadirnya para wirausahawan baru pada kategori ini dapat dijadikan sebagai bukti nyata bahwa usaha jenis mikro, kecil dan menengah (UMKM) mampu mengurangi tingkat pengangguran yang ada. Selain itu, hadirnya para wirausahawan baru yang didominasi wirausaha muda dengan rentang usia antara 15 - 39 tahun ini juga diharapkan bersifat jangka panjang sehingga dapat membuka lapangan pekerjaan bagi para pengangguran terutama dari kalangan lulusan SMU/SMK.

Hal ini merupakan suatu kondisi yang sangat baik dikarenakan kehadiran para wirausahawan muda dapat memberi warna baru bagi dunia kewirausahaan dengan semangat jiwa mudanya. Pada jenjang usia ini biasanya beragam inovasi dan kreativitas bermunculan dilatarbelakangi oleh rasa tidak puas terhadap suatu hal atau ada hal-hal yang tidak sesuai dengan harapannya.

Di sisi lain, keberanian seseorang untuk mendirikan usaha sendiri (wirausaha) sering kali terdorong oleh motivasi pribadi sehingga dapat membangkitkan minat untuk mulai mencoba berwirausaha.

\section{Pengertian Wirausaha}

Hendro (2011) menyebutkan bahwa wirausaha adalah pelaku utama dalam pembangunan ekonomi dan fungsinya adalah melakukan kombinasi-kombinasi yang baru untuk sebuah inovasi. Sedangkan Alma (2013) mendefinisikan wirausaha sebagai orang yang melihat adanya peluang kemudian menciptakan sebuah organisasi dengan tujuan untuk memanfaatkan peluang tersebut. Hampir serupa dengan yang dikemukakan oleh Wibowo (2011) bahwa wirausaha adalah orang yang terampil memanfaatkan peluang dalam mengembangkan usahanya, dengan tujuan untuk meningkatkan kehidupannya.

Jadi wirausaha adalah seseorang yang mampu menciptakan sesuatu yang baru baik barang ataupun jasa dalam suatu organisasi dan mampu mendobrak sistem ekonomi yang ada. Berwirausaha kareanya adalah salah satu cara untuk membangun, memiliki, dan menjalankan usaha agar dapat bermanfaat bagi diri sendiri dan orang lain.

\section{Minat Usaha}

Pengertian minat menurut Kamus Besar Bahasa Indonesia (KBBI) adalah kecenderungan hati yang tinggi terhadap sesuatu; gairah; keinginan. Minat seseorang terhadap sesuatu obyek yang biasanya diawali dari kecenderungan hati seseorang terhadap obyek tertentu. Santoso (1993 dalam Agustina dan Sularto, 2011) memberi definisi minat wirausaha sebagai gejala psikis untuk memusatkan perhatian dan berbuat sesuatu terhadap wirausaha itu dengan perasaan senang dikarenakan membawa manfaat bagi dirinya.

Sejalan dengan itu, Mustofa (2014) mengemukakan bahwa minat berwirausaha merupakan pemusatan perhatian pada wirausaha karena adanya rasa suka dan disertai keinginan mempelajari, mengetahui dan membuktikan lebih lanjut terhadap wirausaha. Seseorang yang berminat terhadap wirausaha akan memiliki kecenderungan hati untuk tertarik menciptakan suatu usaha yang kemudian mengorganisir, mengatur, menanggung risiko dan mengembangkan usaha yang diciptakannya tersebut (Subandono, 2017).

Alma (2013) mengemukakan terdapat beberapa faktor yang mempengaruhi minat berwirausaha, yaitu faktor lingkungan keluarga, faktor lingkungan pendidikan, dan faktor kepribadian. Jadi minat akan tumbuh dan berkembang sesuai dengan faktor-faktor yang mempengaruhinya. Karena pada dasar nya, minat merupakan penerimaan suatu hubungan antara diri sendiri dengan sesuatu diluar pribadi sehingga kedudukan minat tidaklah stabil. Hal ini karena dalam kondisikondisi tertentu, minat dapat berubah-ubah, tergantung kepada factor-faktor yang dinilai mempengaruhinya.

Nursalina (2018) dalam penelitiannya di Kota Makassar menyebutkan bahwa minat berwirausaha mempunyai pengaruh yang positif terhadap keberhasilan usaha mikro kecil berbasis ekonomi kreatif. Oleh karena minat merupakan sesuatu hal yang sangat 
menentukan dalam setiap usaha, maka minat perlu ditumbuhkembangkan pada diri setiap wirausahawan. (Aidha, 2016). Karena minat berwirausaha tidak selalu terbentuk secara otomatis sejak lahir, melainkan dapat ditumbuhkan melalui pendidikan dan pelatihan.

\section{Motivasi Usaha}

Motivasi menurut Kamus Besar Bahasa Indonesia (KBBI) adalah dorongan yang timbul pada diri seseorang secara sadar atau tidak sadar untuk melakukan suatu tindakan dengan tujuan tertentu.

Menurut Sunyoto (2012), motivasi merupakan suatu unsur perangsang keinginan (want) daya penggerak kemauan bekerja seseorang terhadap tujuan tertentu yang ingin dicapai. Peran motivasi dalam berwirausaha dapat dianalogikan sebagai bahan bakar penggerak mesin. Motivasi usaha yang memadai akan mendorong untuk berperilaku aktif dalam berwirausaha. Sedangkan menurut Handoko (2012), motivasi adalah kegiatan yang berakibat, menyalurkan, dan memelihara perilaku manusia.

Dalam konteks kewirausahaan, Wikanso (2013) mengemukakan bahwa motivasi dapat dikatakan sebagai keseluruhan elemen daya penggerak di dalam diri seorang wirausaha yang menimbulkan kegiatan wirausaha yang menjamin kelangsungan dari kegiatan wirausaha dan yang memberi arah pada kegiatan wirausaha tersebut sehingga tujuan yang dikehendaki dapat tercapai. Selanjutnya Gemima et al. (2016) mengatakan bahwa motivasi usaha merupakan suatu kerelaan untuk berusaha seoptimal mungkin dalam mencapai tujuan organisasi yang dipengaruhi oleh kemampuan usaha untuk memuaskan beberapa kebutuhan individu.

Motivasi berwirausaha adalah dorongan kuat dari dalam diri seseorang untuk memulai mengaktualisasi potensi diri dalam berfikir kreatif dan inovatif untuk menciptakan produk baru serta bernilai tambah guna kepentingan bersama (Huarng et al,. 2018). Seorng Wirausaha akan muncul ketika individu tersebut berani mengembangkan usaha-usaha dan ide-ide barunya. Membuat seseorang menjadi berani mengembangkan usaha dan idenya melalui motivasi berwirausaha yang kuat (Minola et al., 2016). Dua hal tersebut harus saling berhubungan agar tercipta wirausaha yang kuat dan tangguh serta berkualitas (Astiti, 2014).

Dalam motivasi terdapat hubungan sistematik antara suatu respons atau suatu himpunan respon dan keadaan dorongan tertentu yang terdiri dari motif, harapan, insentif, laba, kebebasan, impian personal dan kemandirian (Fahmi, 2014). Hal ini berarti bahwa dengan berwirausaha seseorang akan termotivasi memperoleh imbalan minimal dalam bentuk laba, kebebasan, impian personal yang mungkin menjadi kenyataan dan kemandirian di samping memiliki peluang pengembangan usaha serta peluang untuk mengendalikan nasibnya sendiri.

Sebagaimana dijelaskan oleh Venesaar (2006) bahwa motivasi seseorang menjadi wirausaha dibagi dalam tiga dimensi. Dimensi pertama adalah Ambition for Freedom, yaitu aktivitas lebih bebas, memiliki usaha sendiri, menjadi lebih dihormati, terdepan dalam menerapkan ide baru, serta mengembangkan hobi dalam bisnis. Dimensi kedua adalah SelfRealisation, yaitu memperoleh posisi yang lebih baik dalam masyarakat, merasakan tantangan, memotivasi dan memimpin orang lain, melanjutkan tradisi keluarga, mengimplementasikan ide ataupun berinovasi, serta mengikuti orang lain. Dimensi ketiga adalah Pushing Factors, yaitu kehilangan pekerjaan, memperoleh pendapatan yang lebih baik, serta tidak puas dengan pekerjaan.

Jadi motivasi usaha dapat dimaknai sebagai suatu rangsangan yang dapat mendorong seseorang untuk melakukan usaha yang dilakukan dengan penuh semangat, kreatif, inovatif serta berani mengambil risiko dalam rangka memperoleh keuntungan, baik berupa uang (laba) maupun kepuasan diri. Faktor-faktor yang dinilai mempengaruhi motivasi berwirausaha menurut Tuskeroh (2013) antara lain adalah: (1) Rasa percaya diri; (2) Inovatif; (3) Memiliki jiwa kepemimpinan; (4) Efektif dan efisien; serta (5) Berorientasi masa depan.

Penelitian dilakukan Ie dan Visantia (2013) menunjukkan bahwa efikasi diri dan motivasi berpengaruh secara simultan dan 
parsial terhadap keberhasilan usaha pada pemilik toko pakaian di Pusat Grosir Metro Tanah Abang Jakarta. Hasil yang sama juga diperoleh dari penelitian yang dilakukan oleh Daulay (2012) bahwa efikasi diri dan motivasi berpengaruh secara simultan dan parsial terhadap keberhasilan usaha pada usaha fotocopy dan alat tulis kantor di Kecamatan Panyabungan Kabupaten Mandailing Natal.

Pada intinya, motivasi merupakan salah satu faktor keberhasilan wirausaha dalam menyelesaikan tugasnya (Schaltegger \& Burritt, 2018; Carsrud et al., 2017). Semakin besar motivasi maka semakin besar kesuksesan yang bisa dicapai. Faktor-faktor pendorong disebut juga faktor penyebab kepuasan. Adanya kepuasan akan menambah semangat untuk melaksanakan aktivitas.

\section{Keberhasilan Usaha}

Pengertian tentang Keberhasilan usaha menurut Departemen Koperasi dan UKM (2007) merupakan suatu kondisi atau keadaan bertambah majunya suatu maksud dalam suatu kegiatan yang dilihat dari volume usaha, nett asset dan laba bersih. Dari pengertian itu, keberhasilan usaha dapat diartikan suatu kegiatan dengan mengerahkan tenaga dan pikiran agar terjadi perubahan yang lebih baik atau bertambah maju, baik dari segi kualitatif maupun kuantitatif sesuai dengan tujuan yang ditetapkan.

Menurut Suryana (2009), indikator keberhasilan usaha meliputi: (1) modal; (2) pendapatan; (3) volume penjualan; (4) output produksi; dan, (5) tenaga kerja. Selanjutnya
Suryana (2013) juga mengemukakan tiga faktor yang menjadi penyebab keberhasilan seorang wirausaha, seperti: (a) Kemampuan dan kemauan; (b) Tekad yang kuat dan kerja keras; serta, (3) Kesempatan dan peluang.

Dalam penelitiannya, Muzaki (2016) memperoleh hasil bahwa minat dan motivasi usaha berpengaruh secara positif terhadap keberhasilan usaha pada UMKM Desa Jarak Kecamatan Plosoklaten di Kabupaten Kediri. Dengan demikian, hal mendasar yang paling dibutuhkan oleh para wirausaha muda adalah motivasi serta minat yang tinggi agar keberlangsungan hidup usaha yang dijalankannya dapat lebih berumur panjang. Motivasi serta minat itu dapat dipupuk secara terus menerus melalui berbagai penguatan yang mampu menjaga konsistensi dan kestabilannya (Jonker \& Baumgartner, 2017; Barba-Sánchez \& Atienza-Sahuquillo, 2017).

Jika kelangsungan hidup usaha mereka bersifat jangka panjang, maka kehadiran para wirausahawan muda di kota Langsa ini dapat membantu kondisi perekonomian masyarakat secara langsung serta berdampak kepada menurunnya tingkat pengangguran secara jangka panjang. Berdasarkan latar belakang pemikiran tersebut, maka tujuan diadakannya penelitian ini adalah untuk mengetahui pengaruh minat dan motivasi usaha secara parsial ataupun simultan terhadap tingkat keberhasilan usaha para wirausaha muda di Kota Langsa. Kerangka pemikiran dalam penelitian yang meliputi dua variabel bebas dan satu variabel terikat adalah seperti ditunjukkan dalam Gambar 1.

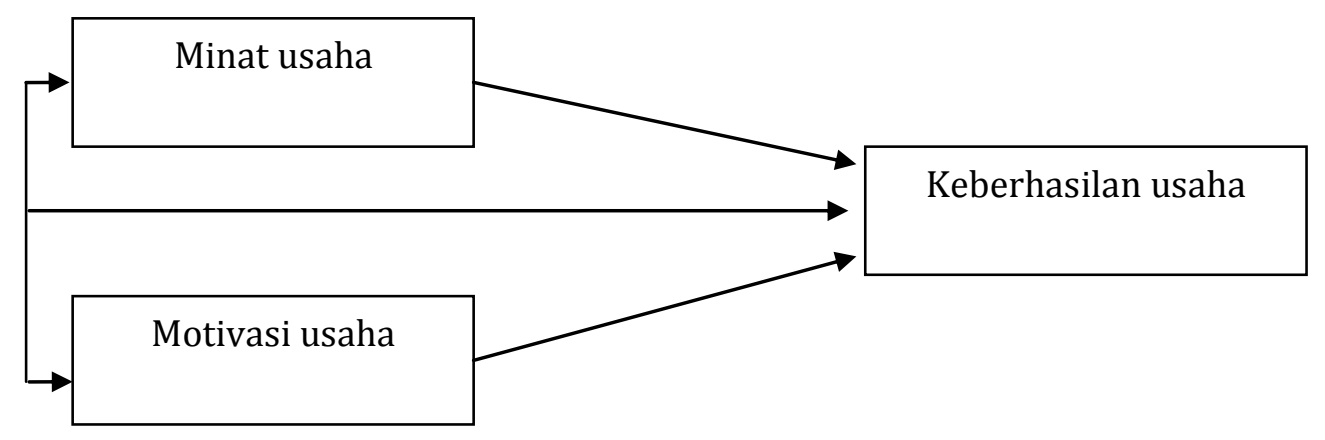

Gambar 1. Kerangka Pemikiran 
Berdasarkan kerangka pemikiran tersebut, maka terdapat tiga hipotesis utama yang diuji dalam penelitian ini, yaitu:

$\mathbf{H}_{\mathbf{1}}$ : Minat usaha dan motivasi usaha secara simultan memiliki pengaruh yang signifikan terhadap keberhasilan usaha.

$\mathbf{H}_{2}$ : Minat usaha secara parsial memiliki pengaruh yang signifikan terhadap keberhasilan usaha.

$\mathbf{H}_{3}$ : Motivasi usaha secara simultan memiliki pengaruh yang signifikan terhadap keberhasilan usaha.

\section{METODE PENELITIAN}

Penelitian ini dilakukan di Kota Langsa Provinsi Aceh, tepatnya di Pusat Pasar Kota Langsa, Pertokoan Langsa Town Square (LATOS) serta Kawasan Pasar Malam Lapangan Merdeka. Pemilihan lokasi penelitian didasarkan atas pertimbangan bahwa lokasi tersebut merupakan pusat-pusat kegiatan wirausaha yang terdapat di Kota Langsa.

Metode penelitian yang digunakan dalam penelitian ini adalah metode kuantitatif dengan menggunakan analisis statistik deskriptif di mana indikator yang dijadikan tumpuan masalah (variabel) akan diuji dengan menggunakan uji statistik kemudian hasil uji statistik tersebut akan digunakan sebagai alat ukur pengaruh antar variabel penelitian.

Populasi adalah wilayah generalisasi yang terdiri atas objek atau subjek yang mempunyai kuantitas atau karakteristik tertentu yang ditetapkan oleh peneliti untuk dipelajari dan selanjutnya ditarik kesimpulannya. (Sugiyono, 2014). Dalam penelitian ini populasi adalah para wirausahawan di Kota Langsa yang tidak diketahui jumlahnya. Sedangkan sampel, masih menurut Sugiyono (2014) adalah bagian dari jumlah dan karakteristik yang dimiliki oleh populasi tersebut. Jadi sampel merupakan bagian dari populasi yang ingin di teliti oleh peneliti.

Pada penelitian ini pengambilan sampel memakai teknik purposive sampling, yaitu teknik penentuan sampel berdasarkan pada pertimbangan tertentu. (Sugiyono, 2014). Alasan digunakannya teknik purposive sampling adalah karena tidak semua sampel memiliki kriteria yang sesuai dengan yang telah ditentukan. Sampel dalam penelitian ini adalah wirausahawan muda dengan rentang usia 20-40 tahun yang telah menjalankan kegiatan usahanya selama minimal 2 tahun. Berdasarkan kriteria tersebut, umlah sampel yang diteliti diperoleh sebanyak 125 sampel.

Dalam penelitian ini alat ukur yang digunakan adalah kuesioner, wawancara, dan lembar pengamatan. Kuesioner yang disebarkan telah diuji terlebih dahulu tingkat validitas dan reliabilitasnya. Pengujian ini dilakukan guna menghasilkan penelitian yang akurat dan konsisten berdasarkan hasil data kuesioner.

Variabel penelitian yang diteliti menggunakan 2 (dua) jenis variabel. Pertama adalah variabel terikat (dependent variable), yaitu variabel yang menjadi pusat perhatian utama penelitian, dimana dalam penelitian ini adalah keberhasilan usaha (Y). Variabel bebas (independent variable) merupakan tipe variabel yang mempengaruhi variabel terikat, baik yang pengaruhnya bersifat positif ataupun negatif. Dalam penelitian ini yang menjadi variabel bebas adalah minat usaha $\left(\mathrm{X}_{1}\right)$ dan motivasi usaha $\left(\mathrm{X}_{2}\right)$.

Dalam penelitian ini data hasil dari kuesioner selanjutnya dianalisis menggunakan teknik analisis regresi linier berganda dengan menggunakan variabel terikat $(\mathrm{Y})$ dan dua variabel bebas $\left(\mathrm{X}_{1}\right.$ dan $\left.\mathrm{X}_{2}\right)$ yang bertujuan untuk menguji hipotesis. Persamaan dari regresi yang digunakan adalah:

$$
\mathrm{Y}=\alpha+\beta_{1} \mathrm{X}_{1}+\beta_{2} \mathrm{X}_{2}+\mathrm{e}
$$

dimana :

$$
\begin{array}{ll}
\mathrm{Y} & =\text { Keberhasilan Usaha } \\
\alpha & =\text { Konstanta } \\
\beta_{1} \beta_{2} & =\text { Koefisien Regresi } \\
\mathrm{X}_{1} & =\text { Minat Usaha } \\
\mathrm{X}_{2} & =\text { Motivasi Usaha }
\end{array}
$$

Koefisien determinasi $\left(\mathrm{R}^{2}\right)$ pada dasarnya digunakan untuk mengukur seberapa jauh kemampuan model regresi dalam menerangkan variasi variabel terikat (Ghozali, 2012). Nilai $R^{2}$ yang kecil berarti kemampuan variabel-variabel bebas di dalam menjelaskan variabel dependen sangat terbatas. 
Pengujian hipotesis menggunakan uji $\mathrm{F}$ ( $F$-test) maupun uji $\mathrm{t}(t$-test). Uji F dilakukan untuk mengetahui pengaruh variabel-variabel bebas secara simultan terhadap variabel terikat. Berikutnya, dilakukan pengujian hipotesis menggunakan uji t bertujuan untuk mengetahui pengaruh parsial dari variabelvariabel bebas terhadap variabel terikat.

\section{HASIL ANALISIS}

\section{Hasil Uji Validitas dan Reliabilitas}

Kuesioner yang disebar kepada responden terlebih dahulu dilakukan uji validitas dan uji reliabilitas. Hasil pengujian validitas atas item-item kuesioner dirangkum pada Tabel 1. Berdasarkan hasil uji tersebut maka dinyatakan bahwa semua item yang diajukan dalam kuesioner kepada responden adalah valid dan bisa digunakan sebagai instrumen penelitian ini. Hal ini karena setiap item kuesioner memiliki nilai r-hitung $>\mathrm{r}$ tabel, sehingga item yang bersangkutan dinyatakan terbukti valid.

Berikutnya, dilakukan uji reliabilitas dimana hasil yang diperoleh terangkum dalam Tabel 2. Dari uji reliabilitas diketahui bahwa semua item pernyataan tentang variabel minat usaha, motivasi usaha dan keberhasilan usaha memiliki nilai Cronbach Alpha > 60. Sehingga berdasarkan pengujian keseluruhan variabel memenuhi reliabilitas, sehingga dinyatakan bahwa kuesioner bisa digunakan sebagai instrumen penelitian ini.

Tabel 1. Hasil Uji Validitas

\begin{tabular}{cccc}
\hline Item & Nilai r-hitung & Kriteria $\boldsymbol{r}$-tabel & Hasil Uji \\
\hline Min1 & 0,251 & 0,195 & Valid \\
Min2 & 0,420 & 0,195 & Valid \\
Min3 & 0,645 & 0,195 & Valid \\
Min4 & 0,418 & 0,195 & Valid \\
Min5 & 0,227 & 0,195 & Valid \\
Min6 & 0,485 & 0,195 & Valid \\
Min7 & 0,454 & 0,195 & Valid \\
Min8 & 0,409 & 0,195 & Valid \\
Min9 & 0,395 & 0,195 & Valid \\
Min10 & 0,497 & 0,195 & Valid \\
Mot1 & 0,686 & 0,195 & Valid \\
Mot2 & 0,305 & 0,195 & Valid \\
Mot3 & 0,543 & 0,195 & Valid \\
Mot4 & 0,326 & 0,195 & Valid \\
Ku1 & 0,404 & 0,195 & Valid \\
Ku2 & 0,529 & 0,195 & Valid \\
Ku3 & 0,520 & 0,195 & Valid \\
Ku4 & 0,429 & 0,195 & Valid \\
\hline
\end{tabular}

Sumber: Data Primer Diolah, 2019

Tabel 2. Hasil Uji Reliabilitas

\begin{tabular}{lccc}
\hline \multicolumn{1}{c}{ Variabel } & Nilai Cronbach Alpha & Kriteria Uji & Hasil Uji \\
\hline Minat Usaha & 73,7 & $>0,6$ & Reliabel \\
Motivasi Usaha & 70,5 & $>0,6$ & Reliabel \\
Keberhasilan Usaha & 70,4 & $>0,6$ & Reliabel \\
\hline
\end{tabular}

Sumber: Data Primer Diolah, 2019 
Tabel 3. Hasil Regresi Berganda dan Uji t

\begin{tabular}{llccccc}
\hline \multirow{2}{*}{ Model } & \multicolumn{2}{c}{$\begin{array}{c}\text { Unstandardized } \\
\text { Coofficients }\end{array}$} & $\begin{array}{c}\text { Standardized } \\
\text { Coefficient }\end{array}$ & \multirow{2}{*}{ t } & \multirow{2}{*}{ Sig. } \\
\cline { 3 - 4 } & Constant & B & Std. Error & B & & \\
\hline 1 & 14,078 & 3,841 & & 3,665 & 0,000 \\
& Minat Usaha & 0,148 & 0,073 & 0,195 & 2,020 & 0,046 \\
& Motivasi Usaha & 0,176 & 0,127 & 0,134 & 1,386 & 0,169 \\
\hline
\end{tabular}

${ }^{a}$ Dependent Variable: Keberhasilan Usaha

Sumber: Data Primer Diolah, 2019

\section{Hasil Analisis Regresi Berganda}

Berdasarkan hasil output SPSS seperti terlihat di dalam Tabel 3, maka diperoleh persamaan regresi bagi penelitian ini adalah:

$$
\mathrm{Y}=14,078+0,195 \mathrm{X}_{1}+0,134 \mathrm{X}_{2}+\mathrm{e}
$$

Berdasarkan persamaan itu dapat dijabarkan beberapa hal. Pertama, hasil analisis menyatakan nilai Konstanta sebesar 14,078; yang berarti bahwa jika minat usaha dan motivasi usaha diasumsikan tetap maka keberhasilan usaha sebesar 14,078 satuan.

Berikutnya, nilai koefisien regresi dari minat usaha $\left(\mathrm{X}_{1}\right)$ adalah sebesar 0,195 yang menyatakan bahwa variabel minat usaha memiliki arah hubungan yang positif terhadap keberhasilan usaha. Hasil itu juga bermakna bahwa jika minat usaha yang dimiliki individu mengalami kenaikan maka tingkat keberhasilan usahanya juga meningkat; sebaliknya, jika minat usaha yang dimiliki individu mengalami penurunan maka tingkat keberhasilan usahanya juga menurun.

Ketiga, nilai koefisien regresi dari motivasi usaha $\left(\mathrm{X}_{2}\right)$ adalah sebesar 0,134 yang menyatakan bahwa variabel motivasi usaha memiliki arah hubungan yang positif terhadap keberhasilan usaha. Hasil itu juga bermakna bahwa jika motivasi usaha yang dimiliki individu mengalami kenaikan maka tingkat keberhasilan dari usahanya juga meningkat; sebaliknya, jika motivasi usaha yang dimiliki individu mengalami penurunan maka tingkat keberhasilan usahanya juga menurun.

\section{Hasil Uji t ( $t$-Test)}

Berdasarkan hasil uji signifikansi parsial (uji t) pada Tabel 3 maka dapat dijelaskan dua pembuktian. Pertama, hasil untuk variabel minat usaha $\left(\mathrm{X}_{1}\right)$ terhadap keberhasilan usaha (Y) menunjukkan nilai Sig. sebesar 0,046 atau lebih kecil dari 0,05 $(\alpha)$. Karena Sig. $<\alpha$ maka dapat dinyatakan bahwa $\mathrm{H}_{0}$ ditolak dan $\mathrm{H}_{\mathrm{a}}$ diterima, artinya variabel minat usaha terbukti secara parsial berpengaruh secara signifikan terhadap keberhasilan usaha.

Kedua, hasil uji t yang diperoleh untuk variabel motivasi usaha $\left(\mathrm{X}_{2}\right)$ terhadap keberhasilan usaha (Y) menunjukkan nilai Sig. sebesar 0,169 atau lebih besar dari 0,05 $(\alpha)$. Karena Sig. $>\alpha$ maka dapat dinyatakan bahwa $\mathrm{H}_{0}$ diterima dan $\mathrm{H}_{\mathrm{a}}$ ditolak, artinya variabel motivasi usaha tidak terbukti secara parsial berpengaruh secara signifikan terhadap keberhasilan usaha. Dengan kata lain, variabel motivasi usaha terbukti secara parsial berpengaruh secara tidak signifikan terhadap keberhasilan usaha.

Secara ringkas, hasil uji $\mathrm{t}$ (t-test) terhadap kedua variabel bebsas yaitu minat usaha dan motivasi usaha memiliki hasil yang berbeda; dimana pada variabel minat usaha terdapat pengaruh secara signifikan terhadap keberhasilan usaha, sementara pada variabel motivasi usaha justru tidak berpengaruh terhadap keberhasilan usaha.

\section{Hasil Uji F (F-Test)}

Berdasarkan Tabel 4, hasil uji signifikansi atas pengaruh simultan (Uji F) diperoleh hasil dari perbandingan nilai Sig. dengan taraf signifikansi $(\alpha)$ adalah 0,048 . Karena nilai Sig. $<\alpha$ lebih kecil dari 0,05 (sig. 0,048<0,05) maka dapat disimpulkan bahwa $\mathrm{H}_{\mathrm{a}}$ diterima dan $\mathrm{H}_{0}$ ditolak. Artinya, variabel minat usaha $\left(\mathrm{X}_{1}\right)$ dan motivasi usaha $\left(\mathrm{X}_{2}\right)$ secara bersama-sama (simultan) terbukti berpengaruh signifikan terhadap variabel terikat, yaitu keberhasilan usaha (Y). 
Tabel 4. Hasil Uji F

\begin{tabular}{llrrrrc}
\hline \multicolumn{1}{l}{ Model } & Sum of Squares & df & Mean Square & F & Sig. \\
\hline 1 & Regressions & 36,395 & 2 & 18,198 & 3,120 & $0,048^{\text {a }}$ \\
& Residual & 589,143 & 101 & 5,833 & & \\
& Total & 625,538 & 103 & & & \\
\hline
\end{tabular}

${ }^{a}$ Predictors: (Constant), Motivasi Usaha, Minat Usaha

${ }^{\mathrm{b}}$ Dependent Variable: Keberhasilan Usaha

Sumber: Data Primer Diolah, 2019

Tabel 5. Hasil Koefisien Determinasi

\begin{tabular}{cccc}
\hline $\mathbf{R}$ & R Square & Adjust R Square & Standard Error of the Estimate \\
\hline 0,176 & 0,127 & 0,134 & 0,169 \\
\hline
\end{tabular}

Sumber: Data Primer Diolah, 2019

\section{Hasil Koefisien Determinasi}

Berdasarkan Tabel 5 diketahui bahwa nilai Adjust $R$ Square adalah 0,040. Angka ini menunjukkan bahwa kedua variabel bebas yaitu minat dan motivasi usaha hanya berkontribusi atau memiliki pengaruh sebesar $4,0 \%$ terhadap keberhasilan suatu usaha. Sedangkan sisanya sebesar $96 \%$ menunjukkan bahwa keberhasilan usaha dipengaruhi oleh variabel-variabel lain yang tidak dicakup dalam model penelitian ini. Dari hasil perolehan nilai $\mathrm{R}^{2}$ yang rendah tersebut, maka dapat diketahi bahwa bagi para wirausaha muda di Kota Langsa ini, ada banyak faktor lain yang mempengaruhi keberhasilan usaha selain minat dan motivasi usaha ini, misalnya modal, pemasaran dan penjualan, ataupun faktor peluang.

\section{Pembahasan}

Berdasarkan hasil kuesioner diperoleh hasil bahwa sebagian besar responden setuju bahwa minat berwirausaha mereka muncul karena faktor-faktor yang mempengaruhinya, dimana dalam penelitian ini merupakan indikator variabelnya. Faktor-faktor tersebut meliputi faktor lingkungan keluarga, faktor kepribadian, faktor lingkungan pendidikan. Dari total responden yang disurvei, sebagian besar menjawab bahwa minat usaha mereka lebih dominan muncul dikarenakan faktor lingkungan keluarga. Misalnya, karena kedua orangtuanya atau saudara terdekat orang tuanya berprofesi sebagai seorang pedagang (wirausaha).
Selain itu, faktor kepribadian juga memberikan andil atas minat berwirausaha, di mana orang-orang yang berkepribadian kuat, tangguh, tahan banting, tidak mudah menyerah akan memiliki minat usaha yang lebih besar dibandingkan yang tidak memiliki kepribadian tersebut. Minat usaha yang tinggi biasanya akan berkorelasi dengan tingkat keberhasilan usaha.

Namun demikian, faktor lingkungan pendidikan ternyata hanya sedikit memberi andil dalam meningkatkan minat usaha. Kemungkinan hal ini disebabkan karena tidak adanya ataupun sedikit sekali materi pembelajaran yang diberikan pihak sekolah atau kampus yang berhubungan dengan dunia kewirausahaan. Sehingga para lulusan baru ini (fresh graduate) belum terlalu tertarik atau berminat untuk terjun langsung berwirausaha dan lebih memilih untuk bekerja menjadi karyawan/pegawai.

Jika dilihat pada faktor motivasi usaha, hasil hipotesis yang menyebutkan bahwa terdapat pengaruh signifikan antara motivasi usaha dan keberhasilan usaha justru tidak terbukti. Karena hasil pengujian yang telah dilakukan menunjukkan bahwa variabel motivasi usaha berpengaruh secara tidak signifikan terhadap keberhasilan usaha. Hal ini bertolak belakang dengan beberapa hasil penelitian yang telah dinyatakan pada telaah konsep dan studi terdahulu tentang motivasi usaha sebelumnya. 
Dari hasil kuesioner yang diberikan oleh responden menunjukan bahwa dari beberapa indikator penelitian variabel motivasi usaha, secara umum memberikan gambaran bahwa motivasi bukanlah yang menjadi penyebab utama dari keberhasilan usaha mereka. Berdasarkan jawaban-jawaban yang diperoleh berdasarkan indikator penelitian untuk variabel motivasi usaha ini lebih banyak yang mengarah kepada jawaban kurang setuju atau tidak setuju. Indikator dari variabel tersebut meliputi ambition of freedom, seperti aktivitas lebih bebas, memiliki usaha sendiri, menjadi lebih dihormati, terdepan dalam menerapkan ide baru, mengembangkan hobi. Self realisation yaitu memperoleh posisi yang lebih baik di masyarakat, adanya tantangan, memotivasi serta memimpin orang lain, melanjutkan tradisi keluarga, mengimplementasikan ide atau berinovasi. Phusing factors meliputi kehilangan pekerjaan, memperoleh pendapatan yang lebih baik, tidak puas pada pekerjaan sekarang.

Sebagian besar responden menganggap bahwa perasaan lebih dihormati dan memperoleh posisi yang lebih baik di masyarakat bukanlah menjadi motivasi bagi mereka dalam berwirausaha. Kemungkinan hal ini karena secara kultural masyarakat di Provinsi Aceh, Kota Langsa khususnya, profesi/pekerjaan sebagai seorang wirausaha masih dianggap kurang bergengsi. Sedangkan profesi/pekerjaan yang lebih dihormati di masyarakat adalah sebagai PNS/ASN.

Selanjutnya, dalam beberapa jawaban kuesioner, sebagian besar responden juga mengungkapkan bahwa keingingan untuk bisa mengimplementasikan ide atau berinovasi, mengembangkan hobi, merasakan tantangan, dan terdepan dalam menerapkan ide-ide baru juga tidak termasuk dalam salah satu faktor yang memotivasi mereka dalam berwirausaha. Faktor terbesar yang menjadi motivasi wirausaha pada sebagian responden adalah karena ingin melanjutkan tradisi keluarga, kehilangan pekerjaan, serta memperoleh pendapatan yang lebih baik.

\section{KESIMPULAN}

Berdasarkan pada data yang dikumpulkan dan pengujian yang telah dilakukan terhadap rumusan masalah, maka dapat diambil kesimpulan berdasarkan hasil uji $\mathrm{t}$ diperoleh hasil bahwa minat usaha secara parsial berpengaruh terhadap keberhasilan usaha para wirausaha muda di Kota Langsa. Sementara itu, berdasarkan hasil uji t juga diperoleh hasil bahwa motivasi usaha secara parsial berpengaruh secara tidak signifikan terhadap keberhasilan usaha para wirausaha muda di Kota Langsa. Terakhir, hasil uji secara simultan menemukan hasil bahwa baik minat usaha maupun motivasi usaha secara bersama-sama berpengaruh secara signifikan terhadap keberhasilan usaha para wirausaha muda di Kota Langsa.

Berdasarkan beberapa kesimpulan tersebut maka saran yang dapat diberikan adalah agar pihak-pihak yang terkait seperti Dinas Koperasi dan UKM ataupun organisasi pengusaha seperti HIPMI (Himpunan Pengusaha Muda Indonesia) Cabang Langsa diharapkan tetap memberikan pembinaan mental kepada para wirausaha muda ini agar dapat meningkatkan minat dan motivasi mereka dalam berusaha, selain juga berupaya memberikan pembinaan lain yang bersifat teknis. Hal ini karena minat dan motivasi yang tinggi dapat membuat kelangsungan hidup usaha yang dijalankan menjadi lebih berumur panjang. Lebih jauh, minat serta motivasi ini dapat dipupuk secara terus menerus melalui berbagai penguatan sehingga mampu menjaga konsistensi dan kestabilan usaha demi perkembangan kegiatan usaha para wirausahawan muda di Kota Langsa.

\section{DAFTAR PUSTAKA}

Agustina, C. dan Sularto, L. 2011. Intensi Kewirausahaan Mahasiswa (Studi Perbandingan antara Fakultas Ekonomi dan Fakultas Ilmu Komputer. Prosiding PESAT (Psikologi, Ekonomi, Sastra, Arsitektur \& Sipil). Depok, tanggal 18-19 Oktober, Universitas Gunadarma. Aidha, Z. 2016. Pengaruh Motivasi terhadap Minat Berwirausaha Mahasiswa Fakultas Kesehatan Masyarakat Universitas Islam Sumatera Utara. JUMANTIK. Vol. 1, No. 1, hal. 42-59. 
Carsrud, A., Brännback, M., Elfving, J. dan Brandt, K. 2017. Motivations: The Entrepreneurial Mind and Behavior. International Studies in Entrepreneurship, Vol. 35, hal. 185-209.

Daulay, R.W. 2010. Efikasi Diri dan Motivasi terhadap Keberhasilan Usaha pada Usaha Fotocopy dan Alat Tulis Kantor di Kecamatan Penyabungan Kabupaten Mandailing Natal. Skripsi. Medan: Universitas Sumatera Utara.

Fahmi, I. 2014. Kewirausahaan: Teori, Kasus dan Solusi. Bandung: Alfabeta.

Gemima, D., Silaningsih, E. dan Yuningsih, E. 2016. Pengaruh Motivasi Usaha terhadap Keberhasilan Usaha dan Kemampuan Usaha sebagai Variabel Mediasi pada Industri Kecil Menengah Makanan Ringan Priangan Timur Indonesia. Jurnal Manajemen Tekno logi. Vol. 15, No. 3, hal. 297-323.

Ghozali, I. 2012. Aplikasi Analisis Multivariate dengan Program SPSS. Semarang: Badan Penerbit Universitas Diponegoro.

Guntoro, H. 2007. Hubungan Prestasi Praktik Kerja Industri terhadap Minat Berwirausaha Siswa Kelas II Tehnik Otomotif SMK Yapin Bekasi Tahun 2007. Skripsi. Semarang: Fakultas Teknik Universitas Semarang.

Handoko, H. 2012. Manajemen. Edisi 2. Yogyakarta: BPFE Yogyakarta.

Huarng, K.H., Mas-Tur, A. dan Yu, T.H.K. 2012. Factors Affecting the Success of Women Entrepreneurs. International Entrepreneurship and Management Journal. Vol. 8, No. 4, hal. 487-497.

https://kbbi.web.id/minat, diakses tanggal 29 Maret 2019.

https://kbbi.web.id/motivasi, diakses tanggal 29 Maret 2019.

Ie, M. dan Visantia, E. 2013. Pengaruh Efikasi Diri dan Motivasi Terhadap Keberhasilan Usaha Pada Pemilik Toko Pakaian di Pusat Grosir Metro Tanah Abang Jakarta. Jurnal Manajemen. Vol. 13, No. 1, hal. 36-48.

Jonker, J. dan Baumgartner, R. J. 2017. Going One's Own Way: Drivers in Developing
Business Models for Sustainability. Journal of Cleaner Production. Vol. 140, No. 1, hal. 144-154.

Minola, T., Criaco, G. dan Obschonka, M. 2016. Age, Culture, and SelfEmployment Motivation. Small Business Economics. Vol. 46, No. 2, hal. 187-213.

Muzaki, A. 2016. Pengaruh Karakteristik, Minat, dan Motivasi Wirausaha terhadap Keberhasilan Usaha pada UMKM Desa Jarak Kecamatan Plosoklaten Kabupaten Kediri. Skripsi. Kediri: Universitas Nusantara PGRI.

Nursalina. 2018. Faktor-Faktor yang Mempengaruhi Keberhasilan Usaha Mikro Kecil Berbasis Ekonomi Kreatif di Kota Makasar. Skripsi. Makasar: Universitas Negeri Makasar.

Rusdiana, H.A. 2014. Kewirausahaan: Teori dan Praktik. Bandung: Pustaka Setia.

Schaltegger, S. dan Burritt, R. 2018. Business Cases and Corporate Engagement with Sustainability: Differentiating Ethical Motivations. Journal of Business Ethics. Vol. 147, No. 2, hal. 241-259.

Subandono, A. 2007. Pengaruh Pembelajaran Life Skill Diklat Kewirausahaan terhadap Minat Berwirausaha pada Siswa SMKN1 Semarang. Skripsi. Semarang: Universitas Negeri Semarang

Sugiyono. 2014. Metode Penelitian Bisnis. Bandung: Alfabeta.

Sunyoto, D. 2012. Manajemen Sumber Daya Manusia. Jakarta: Caps Publishing.

Suryana. 2013. Kewirausahaan (Kiat dan Proses Menuju Sukses). Jakarta: Salemba Empat.

Tuskeroh. 2013. Pengaruh Motivasi dan Mental Berwirausaha pada Mahasiswa Akuntansi Universitas Maritim Raja Ali Haji. Skripsi. Bintan: Universitas Maritim Raja Ali Haji, Kepulauan Riau. Venesaar, E. 2006. Students's Attitudes and Intentions Toward Entrepreneurship at Tallinn University of Technology. TUTWPE Working Papers. No. 154, hal. 97-114. 
Virginia Barba-Sánchez, V. dan AtienzaSahuquillo, C. 2017. Entrepreneurial Motivation and Self-Employment: Evidence from Expectancy Theory. International Entrepreneurship and Management Journal. Vol. 13, No. 4, hal. 1097-1115.
Wikanso. 2013. Pengaruh Pendidikan Kewirausahaan terhadap Motivasi Berwirausaha Mahasiswa STKIP PGRI Ngawi. Media Prestasi : Jurnal Ilmiah STKIP Ngawi. Vol. 11, No. 1, hal. 13. www.depkop.go.id, diakses tanggal 25 Maret 2019.

www.https://langsakota.bps.go.id, diakses tanggal 27 Maret 2019. 